\title{
TERAPI ENDOVASKULAR ANEURISMA KAROTIS KAVERNOSA DENGAN PIPELINE FLEX EMBOLIZATION DEVICE: PENGAMATAN 1 TAHUN
}

\author{
ENDOVASCULAR TREATMENT CAVERNOUS CAROTID ANEURYSM WITH PIPELINE FLEX \\ EMBOLIZATION DEVICE: 1-YEAR FOLLOW UP
}

Muhammad Yunus Amran, *** Seung Pil Ban, ** Ashari Bahar, * O-Ki Kwon**

\section{ABSTRACT}

Asymptomatic intracranial aneurysms are usually detected accidentally through neuroimaging. However, a large intracranial aneurysm (15-24mm) is more likely to manifest clinically due to its mass effect. Aneurysms in the cavernous segment of carotid artery generally exhibit occulomotor nerve palsy, headache and dizziness. The selection of endovascular therapy depends on the type and morphology of the aneurysm. Currently, the treatment options were stent-assisted coil and pipeline embolization device (PED). We reported two cases of large symptomatic unruptured cavernous carotid aneurysm (CCA), treated with the flow diverter technique using a pipeline flex embolization device (PED flex) the second generation of PED. The first case was a 59-year-old woman with complaint of diplopia and headache. Computed Tomography (CT) angiography and 3 dimensional (D) brain imaging revealed bilateral aneurysms, one was in the right cavernous carotid $(16.1 \times 16.6 \mathrm{~mm})$ and the other was in the left cavernous carotid $(9.2 \times 6.5 \mathrm{~mm})$. In second case a 67-year-old woman with complaint of headache. Magnetic resonance angiography (MRA) revealed a $15 \mathrm{~mm}$ aneurysm in the right cavernous carotid. Both aneurysms were treated using PED flex $(4.75 \mathrm{~mm}$ diameter $/ 25 \mathrm{~mm}$ length and $4 \mathrm{~mm}$ diameter $/ 25 \mathrm{~mm}$ length, respectively), except the left cavernous carotid aneurysm in the first case. Six month and one year follow up angiograms were obtained, and showed complete occlusion of aneurysms. Flow diverter technique using PED flex is a feasible and effective treatment for large symptomatic unruptured carotid cavernous aneurysms.

Keywords: Embolization, flow-diverter, large cavernous carotid aneurysms, pipeline flex embolization device (PED flex)

\section{ABSTRAK}

Aneurisma intrakranial asimptomatik biasanya terdeteksi secara tidak sengaja melalui pemeriksaan pencitraan neuroradiologis. Akan tetapi aneurisma intrakranial yang besar $(15-24 \mathrm{~mm})$ cenderung memberikan gejala klinis akibat efek massa yang ditimbulkan. Apabila aneurisma terletak di arteri karotis segmen kavernosa, penderita dapat mengalami paresis nervus okulomotor dan juga terkadang memberikan gejala nyeri kepala serta rasa pusing. Pemilihan terapi endovaskuler bergantung pada tipe dan morfologi dari aneurisma. Saat ini, pemilihan terapi endovaskuler dapat berupa stent-assisted coiling dan alat embolisasi pipeline. Kami melaporkan dua kasus aneurisma karotis kavernosa (AKK) tidak pecah berukuran besar simptomatik dengan teknik flow-diverter menggunakan pipeline flex embolization device (PED flex) yang merupakan generasi kedua dari alat embolisasi pipeline. Pada kasus pertama wanita 59 tahun dengan keluhan diplopia dan nyeri kepala, pemeriksaan Computed Tomography (CT) angiografi dan 3 dimensi (D) otak ditemukan aneurisma pada karotis kavernosa bilateral, yang masing-masing berukuran $(16,1 \times 16,6 \mathrm{~mm})$ pada sisi kanan dan $(9,2 \times 6,5 \mathrm{~mm})$ pada sisi kiri. Pada kasus kedua, wanita 67 tahun dengan keluhan nyeri kepala. Pemeriksaan MRA otak ditemukan aneurisma berukuran $15 \mathrm{~mm}$ pada karotis kavernosa sebelah kanan. Masing-masing aneurisma diterapi dengan PED flex (4,75mm diameter $/ 25 \mathrm{~mm}$ panjang dan $4 \mathrm{~mm}$ diameter $/ 25 \mathrm{~mm}$ panjang), kecuali aneurisma pada karotis kavernosa sebelah kiri pada kasus pertama. Follow-up pada enam bulan dan satu tahun kemudian, dengan pemeriksaan angiografi, menunjukkan oklusi komplet pada masingmasing aneurisma. Terapi endovaskular dengan teknik flow-diverter menggunakan PED flex merupakan modalitas terapi yang efektif dan dapat dilaksanakan untuk aneurisma karotis kavernosa berukuran besar bergejala.

Kata kunci: Aneurisma karotis kavernosa besar, embolisasi, flow-diverter, pipeline flex embolization device (PED flex)

*Divisi Neurologi Intervensi (Terapi Neuroendovaskular), Departemen Neurologi FK Universitas Hasanuddin/Pusat Otak RSUP Dr. Wahidin Sudirohusodo/RS Pendidikan UNHAS, Makassar, Sulawesi Selatan, Indonesia; **Neurointervensi/Intervensi Neuroradiologi, Terapi Neuroendovaskular dan Endovaskular Bedah Saraf, Bagian Neuroendovaskular, Departemen Bedah Saraf, RS Universitas Nasional Seoul Bundang, Seoul, Korea Selatan. Korespondensi: yunusamran10@gmail.com.

Laporan kasus ini pernah dipresentasikan dalam bentuk Poster di acara The 10th National Congress of the Indonesian Neurological Association (INA)/Kongress Nasional ke 10 PERDOSSI, 13 September 2019, Surabaya.

\section{PENDAHULUAN}

Aneurisma intrakranial merupakan suatu kelainan pada pembuluh darah di otak akibat adanya kelemahan pada dindingnya yang menyebabkan outpouching dinding pembuluh darah tersebut, dimana formasi aneurisma intrakranial tersebut dapat diakibatkan oleh stres hemodinamik, disfungsi endothelial dan proses inflamasi. ${ }^{1-2}$ Aneurisma pada 
segmen kavernosa arteri karotis interna merupakan sebuah kelainan patologis yang tidak umum. Hal ini karena terletak pada ruang ekstradural, sehingga apabila ukuran aneurismanya kecil tidak akan berisiko menimbulkan perdarahan subaraknoid. ${ }^{3}$ Angka kejadian aneurisma pada segmen kavernosa arteri karotis interna adalah 3-5\% dari seluruh aneurisma intrakranial dan sekitar 14\% pada seluruh aneurisma di arteri karotis interna. Apabila ukuran aneurismanya besar $(15-24 \mathrm{~mm})$ ataupun bahkan berukuran raksasa $(>24 \mathrm{~mm})$ cenderung akan menimbulkan gejala akibat efek massa yang ditimbulkannya. ${ }^{3}$

Gejala yang ditimbulkan umumnya nyeri kepala yang progresif dan dapat disertai rasa pusing dan pandangan kabur. Juga pernah dilaporkan gejala klinis berupa paresis nervus okulomotorik yang terisolasi ataupun tidak terisolasi walaupun gejala ini bukan merupakan gejala yang umum. ${ }^{4-5}$ Penanganan aneurisma ini sangat tergantung pada tipe, morfologi, patofisiologi terbentuknya aneurisma tersebut dan paling utama faktor risiko yang dapat menyebabkan aneurisma pecah. Beberapa pilihan tata laksana antar lain berupa terapi endovaskuler yaitu balloonassisted coil dan stent-assisted coil, serta penanganan pembedahan. Saat ini salah satu tata laksana pilihan adalah embolisasi menggunakan alat pipeline dengan teknik flow-diverter. Bahkan pada kasuskasus tertentu tidak diperlukan penanganan, hanya dilakukan observasi. Pada laporan kasus serial ini, kami melaporkan dua kasus aneurisma intrakranial berukuran besar pada segmen kavernosa arteri karotis interna. Pada kasus pertama menunjukkan gejala berupa paresis nervus okulomotorik yang terisolasi yang merupakan gejala yang tidak biasa dan pada kasus kedua gejala berupa nyeri kepala disertai pusing. Kedua pasien dilakukan tindakan endovaskuler dengan teknik flow-diverter menggunakan pipeline flex embolization device (PED flex) generasi kedua.

\section{KASUS SERI}

\section{Kasus 1}

Seorang wanita umur 59 tahun masuk ke rumah sakit dengan keluhan nyeri kepala yang dirasakan 3 bulan yang lalu. Nyeri kepala dirasakan pada area oksipital dengan Numeric Pain Rating
Scale (NPRS) 5-6 dan nyeri kepala ini dirasakan semakin memberat. Selain itu, pasien juga merasakan pandangan yang ganda. Riwayat hipertensi ada, riwayat minum obat penurun kolesterol ada. Hasil pemeriksaan neurologis ditemukan adanya right ptosis (right medial gaze palsy). Hasil pemeriksaan Computerized Tomography (CT) scan otak menunjukkan tidak adanya fokal lesi dan perdarahan intrakranial. CT angiografi and 3 dimensional (D) otak menunjukkan adanya aneurisma pada segmen kavernosa arteri karotis interna sisi kanan dengan ukuran $(16,1 \times 16,6 \mathrm{~mm})$; juga terdapat aneurisma pada segmen kavernosa arteri karotis interna sisi kiri dengan ukuran $(9,2 \times 6,5 \mathrm{~mm})$. Tidak terdapat stenosis pada arteri intrakranial dan tidak ada perdarahan intrakranial. Selanjutnya dilakukan pemeriksaan transfemoral cerebral angiography (TFCA) dengan hasil aneurisma unruptured bilateral pada segmen kavernosa arteri karotis interna sisi kanan berukuran besar dengan ukuran maksimal 16,5mm (16,5/width x 13,5/height $\mathrm{x} 10,9 /$ length $\mathrm{mm}$, neck $8,9 \mathrm{~mm})$ dan sisi kiri dengan ukuran maksimal 10,2mm (10,2/ width $\times$ 6,2/height $\times$ 5,2/length $\mathrm{mm}$, neck $6,7 \mathrm{~mm}$ ) (Gambar 1).

Setelah pemberian dua macam obat antiplatelet berupa asam asetilsalisilat (ASA) $100 \mathrm{mg}$ dan clopidogrel bisulfat $75 \mathrm{mg}$ selama 5 hari, maka dilakukan prosedur neurointervensi dengan menggunakan teknik flow-diverter berupa pipeline flex stent ukuran 4,75x25mm (Gambar 2). Dilakukan juga pemeriksaan skull series setelah 3 hari pemasangan stent yang menunjukkan stent dalam keadaan stabil dan tidak ada migrasi stent. Dilakukan pemeriksaan lanjutan berupa CT angiografi dan 3D otak pada bulan ke-2 yang menunjukkan penempatan stent flow-diverter untuk aneurisma pada segmen kavernosa arteri karotis interna sisi kanan dengan ukuran besar dan tidak ada pengisian kontras dalam aneurisma tersebut. Tiga bulan kemudian, pemeriksaan skull series menunjukkan tidak ada bukti migrasi stent.

Pemeriksaan TFCA 6 bulan berikutnya menunjukkan obliterasi yang lengkap pada aneurisma unruptured tersebut di segmen kavernosa arteri karotis 


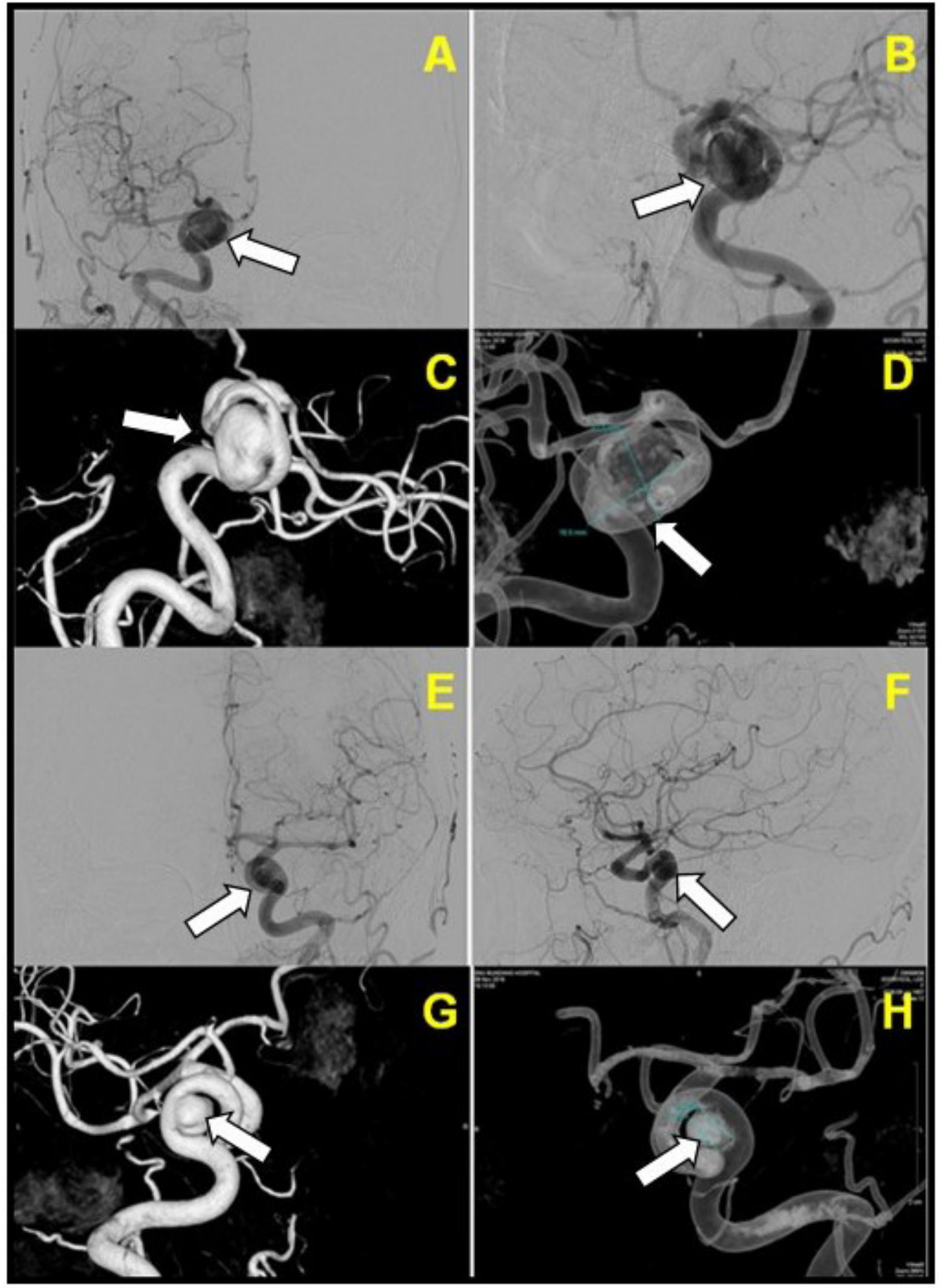

Gambar 1. Transfemoral Cerebral Artery dari Bilateral Unruptured Aneurisma pada Segmen Kavernosa Arteri Karotis Interna Berukuran Besar

A. Anterior posterior view transfemoral cerebral artery aneurisma kavernosa kanan; B. Lateral view transfemoral cerebral artery aneurisma kavernosa kanan; C, D. 3D rotational angiography arteri karotis interna kanan: aneurisma unruptured kavernosa kanan

$(\max 16,5 \mathrm{~mm} ; 16,5 \times 13,5 \times 10,9 \mathrm{~mm}$, neck $8,9 \mathrm{~mm})$; E. Anterior posterior view ransfemoral cerebral artery aneurisma kavernosa

kiri; F. Lateral view transfemoral cerebral artery aneurisma kavernosa kiri; G, H. 3D rotational angiography arteri karotis interna kiri: aneurisma unruptured kavernosa kiri (maksimal 10,2mm; 10,2x6,2x5,2mm, neck 6,7mm) (0 bulan follow up). Panah putih menunjukkan aneurisma.

interna sisi kanan dan tidak ada perubahan pada aneurisma unruptured di segmen kavernosa arteri karotis interna sisi kiri (Gambar 3). CT angiografi dan 3D otak 1 tahun kemudian tetap menunjukkan penempatan stent flow-diverter di aneurisma segmen kavernosa arteri karotis interna kanan tetap stabil dan 


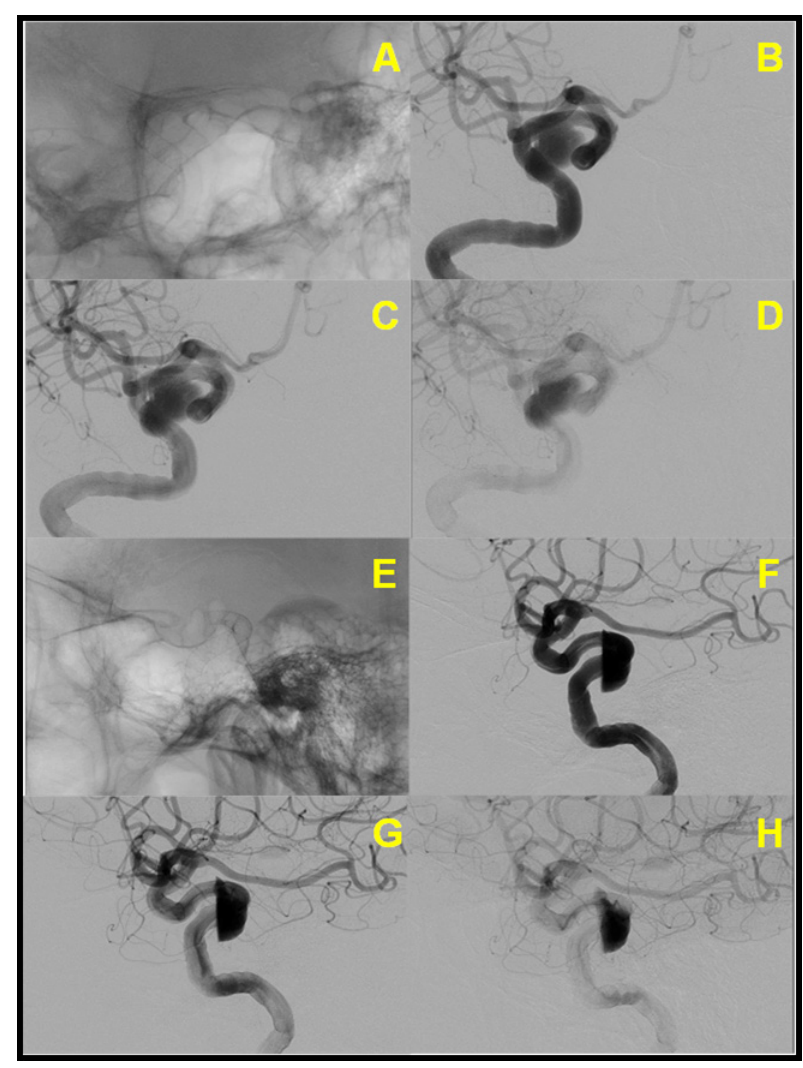

Gambar 2. Pipeline Stent

A. Anterior posterior view transfemoral cerebral artery setelah pipeline stent ditempatkan; B,C,D. Sequential anterior posterior view transfemoral cerebral artery setelah pipeline stent ditempatkan; E. Lateral view transfemoral cerebral artery setelah pipeline stent ditempatkan; F,G,H. Sequential lateral view transfemoral cerebral artery setelah pipeline stent ditempatkan (0 bulan follow up)

tidak ada bukti pengisian kontras di dalam aneurisma tersebut.

\section{Kasus 2}

Seorang wanita umur 67 tahun datang ke rumah sakit dengan keluhan nyeri kepala yang dirasakan sejak setahun yang lalu setelah dilakukan operasi kanker laring. Keluhan dirasakan makin lama makin memberat dan disertai dengan keluhan pusing. Terdapat riwayat hipertensi, tidak ada riwayat diabetes melitus, penyakit jantung dan stroke. Terdapat riwayat operasi kanker laring sejak satu tahun yang lalu. Hasil pemeriksaan neurologis dalam batas normal. Hasil pemeriksaan brain magnetic resonance angiography (MRA) didapatkan adanya aneurisma dengan ukuran $15 \mathrm{~mm}$ pada segmen kavernosa arteri karotis interna kanan dan tidak ada lesi stenosis dan oklusi pada pembuluh darah leher dan intrakranial. Pemeriksaan TFCA dengan hasil angiogram arteri

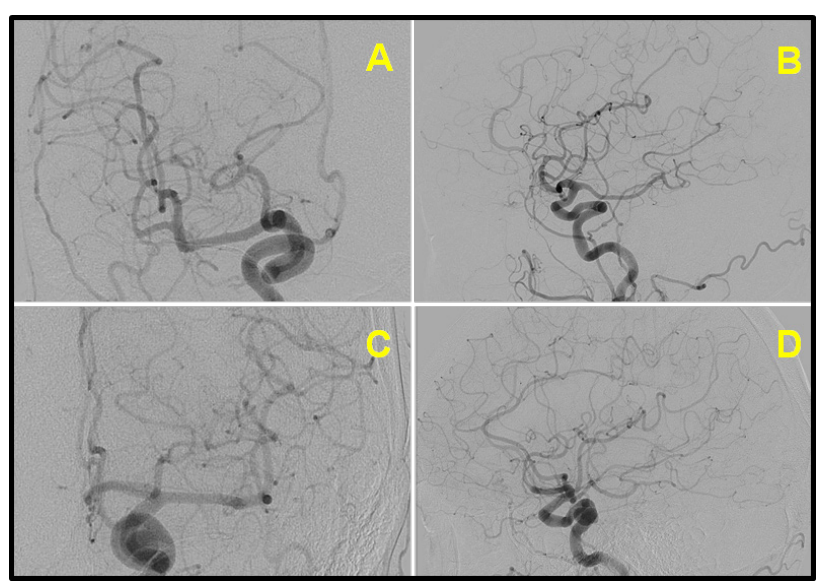

Gambar 3. Transfemoral Cerebral Artery 6 Bulan Follow $U p$

A. Anterior posterior view transfemoral cerebral artery setelah 6 bulan follow up pipeline stent ditempatkan, obliterasi komplit pada aneurisma unruptured kavernosa kanan; B. Lateral view transfemoral cerebral artery setelah 6 bulan follow up pipeline stent ditempatkan, obliterasi komplit pada aneurisma unruptured kavernosa kanan; C. Anterior posterior view transfemoral cerebral artery setelah 6 bulan follow up, tidak ada perubahan yang bermakna pada aneurisma unruptured kavernosa kiri; D. Lateral view transfemoral cerebral artery setelah 6 bulan follow up, tidak ada perubahan yang bermakna pada aneurisma unruptured kavernosa kiri.

karotis interna kanan terdapat aneurisma unruptured segmen kavernosa arteri karotis interna berukuran besar dengan ukuran maksimal 16,9mm (12,4 (height) x 10,4 (length) x 16,9 (width), neck: 9,4mm) (Gambar 4).

Setelah pemberian dua macam obat antiplatelet berupa asam asetilsalisilat (ASA) 100mg dan clopidogrel bisulfat $75 \mathrm{mg}$ selama 5 hari dilakukan prosedur neurointervensi dengan teknikflow-diverter menggunakan pipeline flex stent 4x25mm (Gambar 5).

Pemeriksaan skull series dilakukan 1 hari setelah pemasangan stent dengan hasil yaitu stent dalam keadaan stabil dan tidak ada migrasi. Tiga bulan setelah pemasangan stent pipeline, $\mathrm{CT}$ angiografi and 3D otak dilakukan dengan hasil stent flow diverter pada posisinya untuk aneurisma segmen kavernosa arteri karotis interna kanan ukuran besar; tidak ada bukti pengisian kontras di dalam aneurisma. Transfemoral cerebral angiography 6 bulan follow up menunjukkan obliterasi yang lengkap pada aneurisma unruptured kavernosa kanan (Gambar 6). CT angiografi and 3D otak 1 tahun follow up (FU) menunjukkan stent flow diverter pada posisinya untuk aneurisma pada segmen kavernosa arteri karotis 


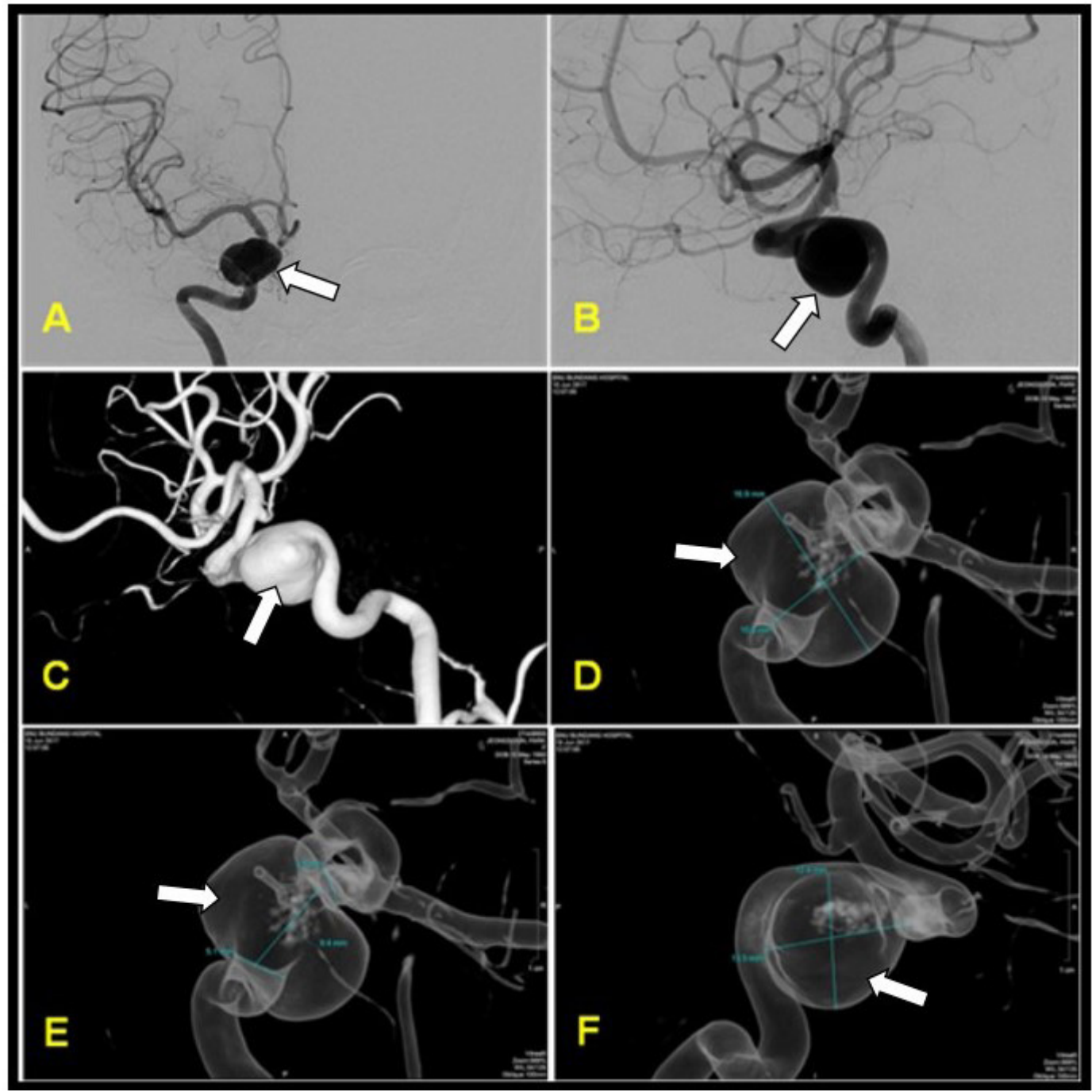

Gambar 4. Transfemoral Cerebral Artery dari Unruptured Aneurisma pada Segmen Kavernosa Arteri Karotis Interna Kanan Berukuran Besar

A. Anterior posterior view; B. Lateral view angiogram arteri karotis interna kanan aneurisma unruptured kavernosa ukuran besar; C,D,E,F. 3D rotational angiography arteri karotis interna kanan terdapat aneurisma kavernosa arteri karotis interna ukuran besar (maksimal 16,9mm;12,4 (height) x 10,4 (length) x 16,9 (width), neck: 9,4mm). Panah putih menunjukkan aneurisma.

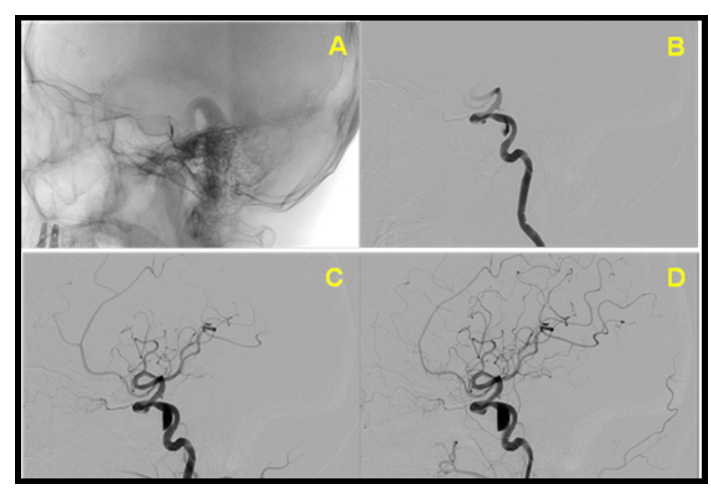

Gambar 5. Pipeline Stent

Penempatan stent yang berhasil pada aneurisma kavernosa arteri karotis interna ukuran besar kanan (maksimal: 17,5mm) A. Lateral view transfemoral cerebral artery setelah pipeline stent ditempatkan; B,C,D. Sequential lateral view transfemoral cerebral artery setelah pipeline stent ditempatkan (0 bulan follow up).

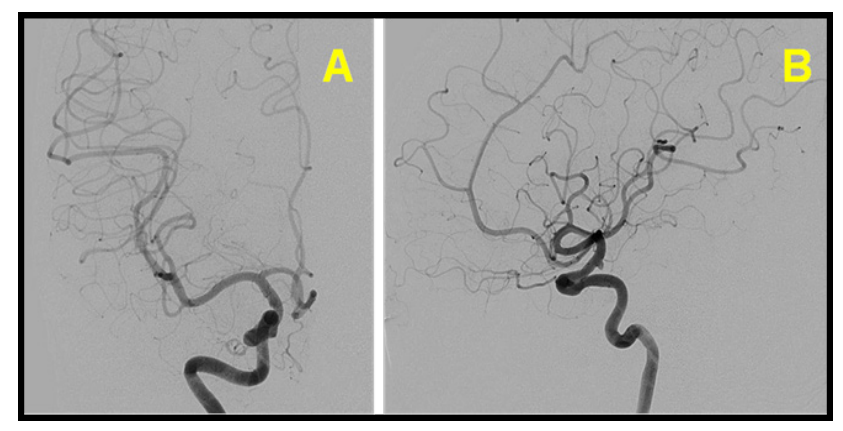

Gambar 6. Transfemoral Cerebral Artery 6 Bulan Follow Up

A. Anterior posterior view transfemoral cerebral artery setelah 6 bulan follow up pipeline stent ditempatkan, obliterasi komplit pada aneurisma unruptured kavernosa kanan; B. Lateral view transfemoral cerebral artery setelah 6 bulan follow up pipeline stent ditempatkan, obliterasi komplit pada aneurisma unruptured kavernosa kanan. 
interna sisi kanan dan tidak ada bukti pengisian kontras dalam aneurisma.

\section{Manajemen Terapi Endovaskuler dan 1 Tahun Follow Up}

Kedua pasien dilakukan tindakan terapi endovaskuler berupa pemasangan stent yaitu pipeline embolization device flex (PED flex; Medtroniclev3/ Covidien, Irvine, California) setelah pemberian dual antiplatelet berupa asam asetilsalisilat (ASA) $100 \mathrm{mg}$ dan clopidogrel bisulfat $75 \mathrm{mg}$ selama 5 hari. Pada kedua pasien setelah dilakukan tindakan anestesi umum kemudian dilakukan tindakan asepsis. Pasien pertama dilakukan penusukan pada arteri femoralis kanan kemudian dipasang $8 \mathrm{Fr}$ long femoral sheath dengan menggunakan 6Fr shuttle guide sheath (Shuttle-SL; Cook, Bloomington, Ind) coaxial dengan 5Fr HN5 (Cook Medical) dilakukan pemilihan arteri karotis interna kanan akan tetapi gagal. 5Fr HN5 (Cook Medical) diganti dengan 5Fr SIM 3 (Cook Medical). Kemudian dengan kateter intermediate $5 \mathrm{Fr}$ Navien (Medtronic) co-axial dengan microcatheter 2,8Fr Marksman (Medtronic) menggunakan microwire Synchro-14 guide (Stryker Neurovascular) untuk menempatkan stent PED flex pada segmen kavernosa arteri karotis interna kanan. Pipeline embolization device flex/PED flex dengan ukuran diameter $4,75 \mathrm{~mm}$ dan panjang $25 \mathrm{~mm}$.

Pasien kedua dilakukan penusukan pada arteri femoralis kanan kemudian dipasang 8Fr femoral sheath. Dengan menggunakan 6Fr shuttle guide sheath (Shuttle-SL; Cook, Bloomington, Ind) coaxial dengan 5Fr Navien (Medtronic) dilakukan pemilihan arteri karotis interna kanan. Kemudian menggunakan microcatheter 2,8Fr Marksman (Medtronic) dengan microwire Synchro-14 guide (stryker neurovascular) untuk menempatkan stent PED flex pada segmen kavernosa arteri karotis interna kanan. Pipeline embolization device flex dengan ukuran diameter $4,0 \mathrm{~mm}$ dan panjang $25 \mathrm{~mm}$. Tidak ada komplikasi selama tindakan berlangsung. Kemudian dilakukan penutupan pada area penusukan dengan menggunakan closure device berupa femoseal dan perclose closure. Kedua pasien mendapatkan dual antiplatelet berupa ASA 100mg dan clopidogrel bisulfat $75 \mathrm{mg}$ satu tahun pertama, kemudian setelahnya antiplatelet tunggal berupa ASA 100mg. Pemeriksaan skull series dilakukan sehari setelah tindakan intervensi untuk melihat penempatan daripada stent. Pemeriksaan follow-up berupa TFCA dilakukan setelah 6 bulan dan CT angiografi and 3D otak setelah 1 tahun pascatindakan pemasangan stent.

\section{PEMBAHASAN}

Prevalensi aneurisma intrakranial terjadi sekitar 2-5\% pada populasi manusia (orang dewasa) dan sekitar 8-10 per 100.000 aneurisma tersebut akan mengalami pecah per tahun. Aneurisma intrakranial yang tidak pecah dapat terdeteksi secara tidak sengaja pada pemeriksaan neuroimaging dan utamanya banyak terdapat pada wanita. Disamping itu, sekitar $7-20 \%$, diketahui bahwa pasien yang memiliki riwayat keluarga, dan kerabat dekat berisiko lebih tinggi, terlepas dari latar belakang etnisnya. ${ }^{6}$

Aneurisma karotis kavernosa (AKK) merupakan suatu penyebab patologi yang tidak umum karena letak aneurisma pada ruang ekstradural. Apabila ukuran aneurismanya kecil maka tidak akan berisiko terjadinya perdarahan subaraknoid, namun apabila ukurannya besar akan menimbulkan tanda dan gejala berupa efek penekanan massa. Etiologi AKK dapat disebabkan karena idiopatik, traumatik, iatrogenik dan infeksi. Traumatik, iatrogenik dan infeksi merupakan penyebab yang sangat agresif dan perlu penanganan neuro-endovaskuler segera. ${ }^{?}$

Aneurisma karotis kavernosa ini dapat diklasifikasikan berdasar-kan ukuran kubah (dome) aneurismanya ke dalam tiga subdivisi yaitu kecil $(<10 \mathrm{~mm})$, besar $(10-24 \mathrm{~mm})$ dan ukuran raksasa $(>24 \mathrm{~mm}) .^{3} \quad$ Gejala klinis yang paling sering ditimbulkan oleh AKK adalah penglihatan ganda dengan tanda presentasi yang paling umum adalah ophthalmoparesis. ${ }^{8-9}$

Goldenberg-Cohen N dkk melaporkan bahwa gejala AKK yang paling sering adalah diplopia (61\%), nyeri kepala (53\%) dan nyeri pada muka atau orbital $(32 \%) .^{10}$

Pada kasus kami keduanya merupakan wanita dan aneurisma terdeteksi karena adanya keluhan berupa nyeri kepala yang disertai dengan pandangan yang ganda serta adanya rasa pusing. Pada 
kasus pertama ditemukan aneurisma unruptured pada karotis kavernosa bilateral dengan ukuran aneurisma yang besar pada sebelah kanan berukuran $16,5 \mathrm{~mm}$ dan sebelah kiri berukuran 10,2mm. Pada kasus tersebut menunjukkan gejala klinis berupa paresis nervus okulomotorius yang terisolasi yang merupakan gejala klinis yang sangat jarang terjadi. Paresis nervus okulomotorius sangat jarang terjadi pada aneurisma di segmen kavernosa, paling sering terjadi apabila aneurisma di arteri communicating posterior (PComA), walaupun pernah dilaporkan gejala tersebut akibat AKK. ${ }^{11}$

Penanganan dengan menggunakan pipeline embolization device flex/ PED flex dengan teknik flow-diverter merupakan penanganan yang digunakan pada kedua pasien kami. PED flex merupakan generasi kedua setelah pipeline embolization device (PED) yang dikeluarkan oleh ev3/Covidien, Irvine, California dan di setujui penggunaannya oleh food and drug administration (FDA) di USA pada tahun 2011.

Pipeline embolization device flex ini merupakan stent yang memiliki lubang yang kecil, yang tetap mempertahankan densitas lubangnya dan merupakan alat yang digunakan pada endoluminal dan dapat mengembang sendiri. Stent ini terdiri dari platinum (25\%) dan paduan kobalt-nikel (75\%) dan bertindak seperti stent berporositas rendah dengan cakupan area permukaan logam $35 \%$ saat digunakan sepenuhnya. ${ }^{12}$ Dengan menggunakan stent PED flex akan menimbulkan aliran pengalihan di dalam kantong aneurisma tanpa mengubah aliran darah pada parent artery-nya, sehingga akan terjadi aliran statis didalam kantong aneurisma dimana akan menimbulkan lokal trombus didalamnya. Teknik ini dikenal dengan istilah flow-diverter. Pada kasus pertama dengan bilateral AKK hanya yang sebelah kanan dilakukan tindakan pemasangan PED flex sementara untuk AKK sebelah kiri tidak dilakukan pemasangan, hanya penanganan secara konservatif berupa pengamatan. Hal ini karena AKK sebelah kanan berukuran $16,5 \mathrm{~mm}$ menimbulkan gejala klinis berupa paresis nervus okulomotorius yang terisolasi, sementara AKK sebelah kiri tidak menimbulkan gejala klinis dan ukurannya yang $<15 \mathrm{~mm}$. Pada kasus kedua dengan AKK sebelah kanan berukuran $16,9 \mathrm{~mm}$. AKK ini menimbulkan gejala klinis berupa nyeri kepala yang makin lama makin progresif. Sebelum dilakukan tindakan pemasangan stent PED flex kedua pasien mengkonsumsi dua macam obat antiplatelet berupa asam asetilsalisilat (ASA) $100 \mathrm{mg}$ dan clopidogrel bisulfat $75 \mathrm{mg}$ selama 5 hari. Pemberian obat antiplatelet bertujuan untuk mencegah terjadinya komplikasi saat tindakan maupun sesudah pemasangan stent PED flex.

Komplikasi yang paling sering terjadi dan paling serius yaitu terbentuknya trombosis di dalam stent (in-device/in-stent thrombosis). ${ }^{13}$ Oklusi cabangcabang arteri perforator, ruptur/perforasi pembuluh darah intraprosedural, edema perianeurismal, infark yang jauh, dan delayed perdarahan merupakan komplikasi-komplikasi yang pernah dilaporkan sebelumnya. ${ }^{13-14}$ Saat ini tidak ada aturan baku mengenai pemberian obat dual antiplatelet sebelum dan sesudah tindakan neurointervensi. Dosis dan lama pemberiannya yang paling sering digunakan adalah ASA dengan dosis 100-325mg dan clopidogrel bisulfat $75 \mathrm{mg}$ per hari selama 5-10 hari sebelum prosedur tindakan dilakukan. Setelah prosedur tindakan intervensi dilanjutkan dengan pemberian ASA dengan dosis 100-325mg dan clopidogrel bisulfat $75 \mathrm{mg}$ per hari selama 6 bulan. Kemudian clopidogrel bisulfat $75 \mathrm{mg}$ dihentikan pemberiannya dan ASA dengan dosis 100-325mg tetap dilanjutkan. Penghentian obat ini dapat dilakukan sesuai dengan hasil angiografinya dan kondisi klinis pasien. ${ }^{15,16}$ Pada kasus kami, kedua pasien diberikan dua macam obat antiplatelet yaitu ASA dengan dosis 100mg dan clopidogrel bisulfat $75 \mathrm{mg}$ per hari selama 5 hari sebelum tindakan prosedur dilakukan. Sesudah tindakan dilakukan diberikan ASA dengan dosis $100 \mathrm{mg}$ dan clopidogrel bisulfat $75 \mathrm{mg}$ per hari selama 1 tahun, kemudian clopidogrel bisulfate $75 \mathrm{mg}$ dihentikan. Sementara pemberian ASA dengan dosis 100mg tetap dilanjutkan selama 1 tahun.

Setelah dilakukan prosedur pemasangan stent PED flex, dilakukan pemeriksaan skull series sehari setelahnya. Tujuannya untuk melihat posisi daripada stent. Trans femoral cerebral angiography dilakukan 6 bulan setelah pemasangan stent PED flex. Hasil 
kedua pemeriksaan tersebut menunjukkan posisi stent tetap pada tempatnya dan oklusi yang sempurna tampak pada kedua AKK. Satu tahun setelah pemasangan stent PED flex dilakukan pemeriksaan neuroimaging berupa $\mathrm{CT}$ angiografi dan 3D otak pada kedua pasien. Pada pemeriksaan tersebut didapatkan hasil berupa stent PED flex terletak pada posisinya, tidak ada tanda-tanda pengisian kontras kedalam AKK dan aliran darah ke distal yang paten. Kedua pasien memperlihatkan perbaikan gejala klinis setelah dilakukan tindakan pemasangan PED flex.

\section{KESIMPULAN}

Penanganan aneurisma karotis kavernosa memerlukan pertimbangan yang cermat, hal ini karena tidak semua aneurisma harus dilakukan tindakan neurointervensi. Hal yang sangat penting adalah apakah aneurisma ini memberikan gejala klinis, ukuran yang besar sampai dengan raksasa, faktor-faktor yang terdapat pada pasien seperti usia, komorbid dan natural history dari aneurisma. Sehingga dalam penanganan aneurisma dapat dilakukan melalui pendekatan pembedahan berupa klipping aneurisma, endovaskuler balloon-assisted coil atau stent-assisted coil dan penanganan konservatif saja. Flow-diverter dengan menggunakan stent PED flex merupakan modalitas terapi yang efektif dan dapat dilaksanakan untuk aneurisma karotis kavernosa berukuran besar bergejala pada saat ini.

\section{DAFTAR PUSTAKA}

1. Samaniego EA, Roa JA, Hasan D. Vessel wall imaging in intracranial aneurysms. J Neurointerv Surg. 2019;11(11):1105-12.

2. Ajiboye N, Chalouhi N, Starke RM, Zanaty M, Bell R. Unruptured cerebral aneurysms: evaluation and management. Scientific World Journal. 2015; 2015:954954.

3. Sriamornrattanakul K, Sakarunchai I, Yamashiro K, Yamada Y, Suyama D, Kawase T, dkk. Surgical treatment of large and giant cavernous carotid aneurysms. Asian J Neurosurg. 2017;12(3):382-8.

4. Lai G, Rodriguez MI, Scumpia AJ. Oculomotor nerve palsy secondary to cavernous internal carotid aneurysm. Clin Pract Cases Emerg Med. 2018;2(1):93-4.

5. Kung NH, Van-Stavern GP. Isolated ocular motor nerve palsies. Semin Neurol 2015;35(5):539-48.

6. Xu Z, Rui YN, Hagan JP, Kim DH. Intracranial aneurysms: pathology, genetics, and molecular mechanisms. Neuromolecular Med. 2019;21(4):325-43.

7. Welch BG, Batjer HH. Cavernous carotid aneurysms: you can but should you? World Neurosurg. 2014;82(6):996-7.

8. Kupersmith MJ, Berenstein A, Choi IS, Ransohoff J, Flamm ES. Percutaneous transvascular treatment of giant carotid aneurysms: neuro-ophthalmologic findings. Neurology. 1984;34(3):328-35.

9. Junior JR, Oliveira LM, Boechat AL, Teixeira MJ, Figueiredo EG. Cavernous carotid artery aneurysms on a single institution: an epidemiological study with 201 patients. Clin Neurol Neurosurg. 2019; $186: 105504$.

10. Goldenberg-Cohen N, Curry C, Miller NR, Tamargo RJ, Murphy KP. Long term visual and neurological prognosis in patients with treated and untreated cavernous sinus aneurysms. J Neurol Neurosurg Psychiatry. 2004;75(6):863-7.

11. Amin MN, Vassallo J, Butler L, Catania JD. A man with headache and double vision. Bmj. 2015;351:5375.

12. Gawlitza M, Soize S, Manceau PF, Pierot L. An update on intrasaccular flow disruption for the treatment of intracranial aneurysms. Expert Rev Med Devices. 2019;16(3):229-36.

13. Aguilar-Salinas P, Brasiliense LB, Gonsales D, Mitchell B, Lima A, Sauvageau E, dkk. Evaluation of pipeline flex delivery system for the treatment of unruptured aneurysms. Expert Rev Med Devices. 2016;13(10):885-97.

14. Cagnazzo F, Mantilla D, Rouchaud A, Brinjikji W, Lefevre PH, Dargazanli C, dkk. Endovascular treatment of very large and giant intracranial aneurysms: comparison between reconstructive and deconstructive techniques-a meta-analysis. AJNR. 2018;39(5):852-8.

15. Kim KS, Fraser JF, Grupke S, Cook AM. Management of antiplatelet therapy in patients undergoing neuroendovascular procedures. J Neurosurg. 2018; 129(4):890-905.

16. Runjaic S, Nordeen JD, Soto-Arenall MW, Johns GS, Miller D, Brown B, dkk. Safety and efficacy of intensified antiplatelet therapy in patients undergoing neuroendovascular procedures. J Vasc Interv Neurol. 2017;9(3):51-6. 